\title{
ОСОБЕННОСТИ СОМАТИЧЕСКОГО СТАТУСА ДЕТЕЙ С ВПЕРВЫЕ ВЫЯВЛЕННЫМ САХАРНЫМ ДИАБЕТОМ 1 ТИПА
}

\author{
Т.В. Варламова', Е.В. Хомякова², Ю.Р. Зарипова', Д.Б. Бабогло' \\ 'Петрозаводский государственный университет, Петрозаводск, Россия \\ ${ }^{2}$ ГБУЗ «Детская республиканская больница», Петрозаводск, Россия
}

Высокая распространенность сахарного диабета 1 типа (СД1), манифестация в детском и подростковом возрасте, развитие осложнений, ухудшающих качество и продолжительность жизни являются актуальными проблемами системы здравоохранения. Отмечается неуклонный рост заболеваемости СД1 среди детей и подростков, что отмечается и в Республике Карелия. Высокая частота заболеваемости СД1 детского населения соседней с Карелией Финляндии, имеющей общие этнические и культурные корни, а также климатогеографическую близость, повышает актуальность изучения этой эндокринной патологии

ЦЕЛЬ РАБОТЫ - провести оценку соматического статуса детей с впервые выявленным СД1.

Проведен анализ историй болезни 236 пациентов (из них мальчиков 57,2\%) с впервые выявленным СД1 за 2005-2021 гг., находившихся на лечении в Центре детской эндокринологии и гастроэнтерологии ГБУЗ «Детская республиканская больница» Республики Карелия.

Наибольшее число заболевших было выявлено в 6, 8 и 11 лет. Пики заболеваемости приходились на весенне-осенний периоды. Степень выраженности клинических проявлений заболевания зависит от возраста, дебюта и стадии в период выявления. В семьях детей, больных СД1, имеет место эффект накопления генов, и отмечается «синдром упрежения»: СД1 развивается в более молодом возрасте, чем у родителей, и протекает тяжелее. В последнее время число больных СД1 растет преимущественно за счет детей до 5 лет. Это так называемое «омоложение СД1», то есть тенденция к более высокой частоте заболевания детей в раннем возрасте. Особенностью СД1 у детей данной возрастной группы является острое начало заболевания с быстрым развитием диабетического кетоацидоза. Из 236 случаев в 50,4\% СД1 типа был диагностирован в состоянии диабетического кетоацидоза.

Отягощенная наследственность по аутоиммунным заболеваниям (СД1, аутоиммунный тиреоидит (АИТ), диффузный токсический зоб) была выявлена только у 8\% пациентов, по другим эндокринным заболеваниям (СД 2 типа, ожирение, диффузный нетоксический зоб) - в 31\% случаев.

При обследовании детей с СД1 были выявлены: атопический дерматит в 11,1\%, патология сердечно-сосудистой системы в 57\%, патология мочевой системы в 18\%, нарушение опорно-двигательного аппарата в 11\%, заболевания нервной системы в 6\%, АИТ в 13\% случаев.

Таким образом, впервые выявленный СД1 наиболее часто сочетается с АИТ. Антитиреоидные антитела в сыворотке крови присутствовали у $20 \%$ больных СД1, что значительно выше по сравнению с детьми без СД1. Высокая частота сочетания СД1 и АИТ требует обязательного обследования щитовидной железы как при впервые выявленном СД1, так и в динамике. 